\title{
CHEMICAL AND ORGANOLEPTIC PROPERTIES OF BEKAI (Pycnarrhena tumefacta Miers) LEAVES FOR FLAVOURING AGENT (BIO-VETSIN)
}

\author{
Rizki Maharani ${ }^{* 1}$, Andrian Fernandes ${ }^{1}$, Maman Turjaman², Harlinda Kuspradini ${ }^{3}$, \\ and Ganis Lukmandaru ${ }^{4}$ \\ ${ }^{1}$ Dipterocarps Research Institute, Research, Research, Development, and Innovation Agency (FORDA), \\ The Ministry of Environment and Forestry \\ Jalan A.W. Syahranie No 68, Samarinda, East Kalimantan, Indonesia \\ ${ }^{2}$ Forest Research and Development Center, Research, Development, and Innovation Agency, \\ Ministry of Environment and Forestry, Indonesia \\ ${ }^{3}$ Wood Chemistry Laboratory, Mulawarman University, Samarinda, East Kalimantan, Indonesia \\ ${ }^{4}$ Wood Chemistry Laboratory, Forestry Faculty, Gadjah Mada University, Yogyakarta, Indonesia
}

Received: 17 April 2020, Revised: 26 October 2020, Accepted: 27 October 2020

CHEMICAL AND ORGANOLEPTIC PROPERTIES OF BEKAI (Pycnarrhena tumefacta Miers) LEAVES FOR FLAVOURING AGENT (BIO-VETSIN). The "tasty" cuisine tends to use chemical flavour agent containing monosodium glutamate (MSG). Utilization of MSG, in long-term, may cause health problems, especially triggering cancer cells. Therefore, it is necessary to introduce and increase a natural flavouring agent to eliminate those health problem, such as bekai leaf. Bekai (Pycnarrhena tumefacta Miers) is familiar as a natural flavour agent (bio-vetsin) in cuisine for forest communities in Nyapa Indah Village, Berau, East Kalimantan, Indonesia. However, until now there has been no proper analysis support for widespread utilization of bekai leaf. This paper studies the presence of phytochemicals, antioxidant and GC MS analysis from bekai leaf extracts, as well as five hedonic classifications of organoleptic test, to reinforce the need for a better understanding of consumers reaction in terms of possible acceptance of additional bekai leaves applied in soup as bio-vetsin. Present study showed that the qualitative screening of phytochemical compounds in bekai leaves ethanolic extracts revealed presence of alkaloids, flavonoids, tannins and steroids. Antioxidants of bekai leaves using 2,2-diphenyl-1-picrylhydrazy (DPPH) method showed that concentrated extract has $80.1 \%$, which was predicted can improve immune for inhibitory action of cancer cells. GC MS analysis suspected that bekai leaf extract contained five major compounds, i.e. oxirane dodecyl, gamma sitosterol, vitamin E ( $\alpha$ tokoferol), 9.12-Octadecadienoic acid (Z,Z)- (natural linoleic acid), and 3-Tetradecanynoic acid (myristic acid). These chemical compound in related with their phytochemical were predicted to contain strong antioxidant activities and some of them are commonly used as flavour agent in cuisine for some food industries. Meanwhile, results of organoleptic tests presence in three soup variant showed that soup with additional bekai leaves has best acceptance in the children's perception due to unique smell, tasty and no colour changing compared with added MSG and control. Thus bekai leaf can be used as an innovation for healthy food and new market opportunities for MSG substitutes.

Keywords: Bekai leaf, phytochemicals, antioxidants, GC-MS, flavouring agent, organoleptic

KARAKTERISTIK KIMLA DAN ORGANOLEPTIK DAUN BEKAI (Pycnarrhena tumefacta Miers) UNTUK PENYEDAP ALAMI (BIO-VETSIN). Masakan "enak" cenderung menggunakan baban penyedap kimia yang mengandung monosodium glutamat (MSG). Pemanfaatan MSG dalam jangka panjang dapat menyebabkan gangguan kesehatan, terutama pemicu sel kanker. Oleb karena itu perlu dilakukan pengenalan dan penambahan zat penyedap alami untuk. mengatasi gangguan kesebatan tersebut, seperti daun bekai. Bekai (Pycnarrhena tumefacta Miers) dikenal sebagai penyedap alami (bio-vetsin) dalam masakan oleh masyarakat di Desa Nyapa Indah, Berau, Kalimantan Timur, Indonesia. Namun bingga saat ini belum ada dukungan analisis yang tepat untuk. pemanfaatan daun bekai secara luas. Penelitian ini menentukan keberadaan fitokimia, anti oksidan dan analisis GC MS dari ekstrak daun bekai, serta lima klasifikasi bedonik uji organoleptik, untuk memperkuat perlunya pemahaman yang lebih baik tentang reaksi konsumen dalam hal kemungkinan penerimaan penyedap asal daun bekai yang ditambabkan dalam sup sebagai bio-vetsin. Penelitian terbaru

${ }^{* *}$ Corresponding author: rizma_annisa@yahoo.com 
menunjukkan babwa skrining kualitatif senyawa fitokimia pada ekstrak etanol daun bekai menunjuk.kan adanya alkaloid, flavonoid, tanin dan steroid. Anti oksidan daun bekai dengan metode 2,2-difenil-1-pikrilhidrol (DPPH) menunjuk.kan ekstrak pekat memiliki kandungan 80,1\% yang diperkirakan dapat meningkatkan kekebalan tubuh untuk menghambat aksi sel kanker. Analisis GC MS diduga ekstrak daun bekai mengandung 5 (lima) senyawa utama yaitu oksiran dodesil, gamma sitosterol, vitamin E (a tokoferol), 9.12-oktadekadienoat (Z, Z) - (asam linoleat alami), dan 3-Tetradekanynoat (asam miristat). Senyawa kimia yang terkait dengan fitokimianya diduga mengandung aktivitas antioksidan yang kuat dan beberapa di antaranya biasa digunakan sebagai agen penyedap masakan pada beberapa industri makanan. Sedangkan dari hasil uji organoleptik. keberadaan tiga varian soto menunjukkan bahwa dengan tambahan daun bekai paling diterima persepsi anak-anak karena memiliki bau yang kbas, gurib dan tidak berubah warna dibandingkan dengan penambahan MSG dan kontrol. Dengan demikian daun bekai dapat digunakan sebagai inovasi untuk makanan sehat dan peluang pasar baru untuk pengganti MSG.

Kata kunci: Daun bekai, phytochemical, anti-oksidan, GC-MS, penyedap alami, organoleptik.

\section{INTRODUCTION}

People choose high quality food that provide health benefits by adding certain ingredients (additives) in food (Sauceda, Martinez, Rodriguez, Aguilar, \& Zavalal, 2016). An increase in economic rate raises the population's awareness of food additives usages (Kumar, Singh, Chandra \& Samsher, 2017). These additive materials have begun to shift from factory synthesis materials, such as MSG (Monosodium glutamate) to natural ingredients. This is because to MSG utilizations, in longterm, can become a toxic and possibly threat to public health, especially triggering cancer cells (Niaz, Zaplatic \& Spoor, 2018).

Indonesia is one of the countries with megabiodiversity and some plants are potentially used for food spices and herbs (Supartono, Sukartiko, Yuliando, \& Kristanti, 2015). Some spices and herbs are known to be used as cuisine ingredients such as ginger and galangal. Ginger (Zingiber officinale) is extensively used around the world in cuisine as a spice (Ghosh, Banerjee, Mullick, \& Banerjee, 2011). While, Alpinia galanga (galangal) is rhizome used as spice and flavouring agent and its leaves and inflorescence are consumed as vegetable (Wong, Lim, \& Omar, 2008). There are many other potentials of herbal plants in Indonesia that has a function as natural flavouring agent and can be used as an MSG substitute.

One of the potential herbaceous plants as natural flavouring agent is bekai (Pycnarrbena tumefacta Miers) from Menispermaceae family. Hereditary, local community of Nyapa Indah Village, Berau District, East Kalimantan, Indonesia planted bekai both on local yard and under forest tree stands (Figure 1). Usually bekai leaves are added into cuisine which meat as basic ingredients, while for other cuisine has never been tried. Besides for accelerating process of meat into well-done, bekai leaves could also be used as natural flavouring agent. However, there has been no research publication available on the content of chemical compounds and also organoleptic tests on cuisine or food with additional bekai leaves (Pycnarrhena tumefacta Miers). As a comparison in other genera with different species, namely sengkubak (Pycnarrbena cauliflora (Miers) Diels) in West Kalimantan, the community have used it as a basic ingredient for accelerating process of meat and savoury flavours in food. Pycnarrhena cauliflora (Miers) Diels has roots that are predicted to play a role as cytotoxic and pro-apotic activities in human breast cancer (Masriani, Mustofa, Jumina, Sunarti, \& Enawaty, 2014). Further, Masriani, Mustofa, Jumina and Sunarti (2013) stated that the ethanolic extracts from root, stem and leaves of $P$. cauliflora inhibited the growth of HeLa cells (cervical cancer cell).

Development of novel foods by adding functional component to carrier food provides new market opportunities for manufacturers (Pestoric et al., 2015). In order to be successful on the market a product or product category 
needs to both benefit from positive general image and offer product qualities that match or surpass consumers' expectations (Almli, Verbeke, Vanhonacker, Naes, \& Hersleth, 2011). Thus, a considerable proportion of product failure can be attributed to a mismatch between sensory properties and consumer needs or expectations (Kemp, Hollowood, \& Hort, 2009). The positive general image of consumer through human senses include colour, odour, taste, and others special feature were necessary to maintain reproducible efficacy and safety of herbal product as rational drug (Bisla, Choudhary, \& Chaudhary, 2014).

In the present study, some chemical properties of bekai leaves were determined as a natural flavouring agent (bio-vetsin), especially for others cuisine (i.e. soup). This study also provided organoleptic data of its cuisine products to reinforce the need for a better understanding of consumers reaction in terms of possible acceptance of additional bekai leaves as an innovation for healthy food and new market opportunities for MSG substitutes.

\section{MATERIAL AND METHOD}

\section{A. Materials}

Fresh leaves of bekai (Pycnarrhena tumefacta Miers) were collected from Custom Forest of Nyapa Indah Village (around Labanan Forest
Research), Berau District, East Kalimantan,

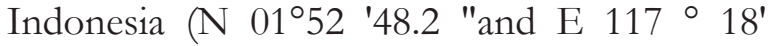
03.2"). Bekai leaves were dried in the laboratory with air conditioned (A.C.) set for $25^{\circ} \mathrm{C}$ for 3 days and ground to a fine powder using crusher and sieved through 40-60 mesh. The powder samples were kept at A.C. room in a covered glass container to protect them from humidity and light prior to extraction. Then these samples were prepared for further analysis.

\section{B. Methods}

\section{Maceration}

Five grams dried powder of bekai leaves were exhaustively extracted by maceration in $200 \mathrm{ml}$ ethanolic solvent for 24 hours at room temperature $\left(28+2^{\circ} \mathrm{C}\right)$. Whereas, each extraction was concentrated from $200 \mathrm{ml}$ into $10 \mathrm{ml}$ concentrated crude ethanolic extracts, dried in oven at $50^{\circ} \mathrm{C}$ to give dark green extracts (Maharani et al., 2016; Zhang et al., 2018). Further, these extracts were used for phytochemical and antioxidant analysis $(5 \mathrm{ml})$, and GC-MS analysis (5 ml).

\section{Antioxidant Assay}

In this antioxidant test, $100 \%$ of 5 concentrated samples were grouped into 200 ppm, $100 \mathrm{ppm}, 50 \mathrm{ppm}$ and $25 \mathrm{ppm}$ times of dilution, respectively. Further, $1 \mathrm{mg}$ of vitamin $\mathrm{C}$ was weighed, then dissolved in $5000 \mu \mathrm{l}$ of

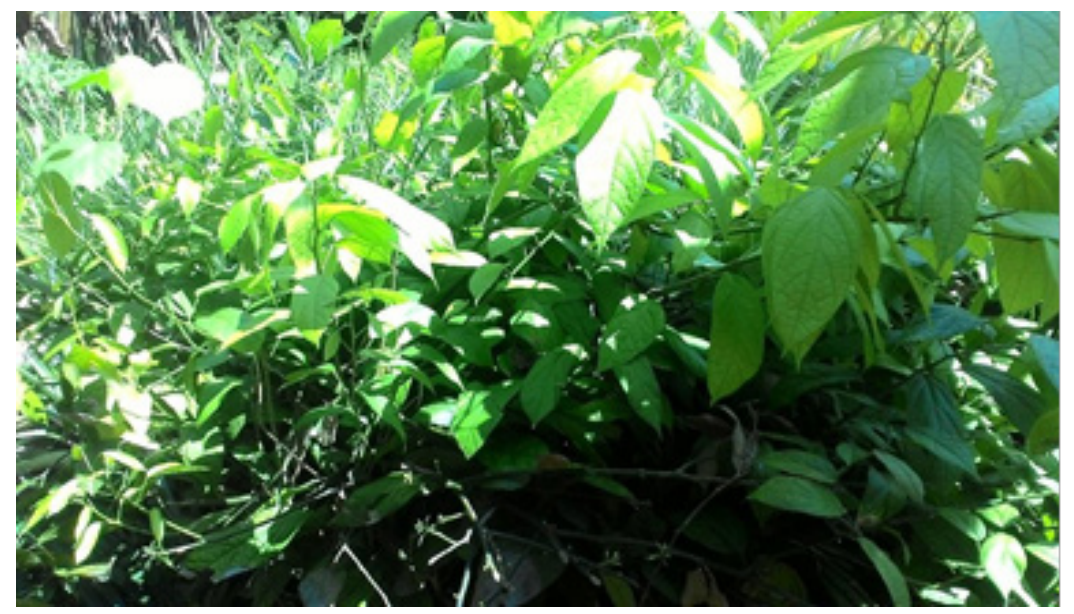

(a)

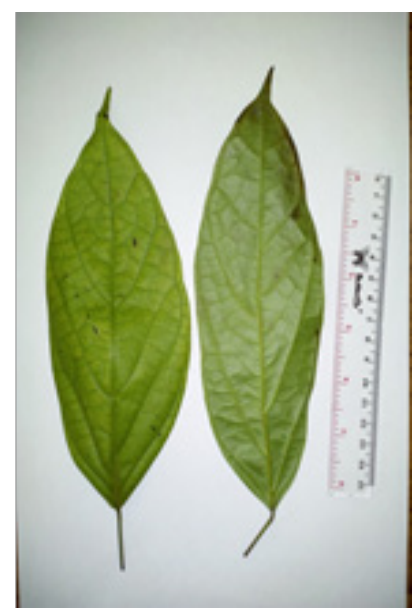

(b)

Figure 1. Bekai planted in forest community area (a), and bekai leaf used for natural flavouring agent (b) 
distilled water and regarded as a positive control. While, negative control was used its solvent (distilled water) (Fitriana, Istiqomah, Ersam, \& Fatmawati, 2018), $100 \mu$ l sample was mixed in cuvette with $400 \mu \mathrm{l}$ of distilled water was added, and $500 \mu \mathrm{l}$ of 2,2-diphenyl1-picrylhydrazy (DPPH) radical scavenging activity. Mixing was stopped when the sample volume has reached $1000 \mu \mathrm{l}(1 \mathrm{ml})$. Samples were incubated for 20 minutes indoor with minimum light. The antioxidant activity was determined by decolorization of DPPH with a wavelength of $517 \mathrm{~nm}$ using a spectrophotometer. The scavenging activity was calculated as a percentage of DPPH decolouration relative to a negative control using equation 1 (Maheswari, Reena, \& Sivaraj, 2017).

\section{Analysis}

\section{Preliminary Phytochemical Analysis}

Bekai extracts were tested for active compound such as flavonoids, saponins, steroids, tannins, terpenoids, alkaloids and carbohydrate using some following standard procedures (Keo et al., 2017; Jaradat, Hussen, \& Ali, 2015).

\section{Flavonoids Determination}

About $1 \mathrm{ml}$ of ethanolic extract was mixed and shaken with $1 \mathrm{ml}$ of dilute ammonia solution. The layers were allowed to separate and the yellow color in the ammonical layer (bottom layer) indicates the presence of flavonoids (Jaradat et al., 2015).

\section{Saponins Determination}

Five $\mathrm{ml}$ of the filtrate was diluted into $20 \mathrm{ml}$ of water and shaken vigorously (15 minutes). A stable froth (foam) upon standing indicates the presence of saponins (Keo et al., 2017).

\section{Steroids Determination}

One ml of ethanolic extract of each sample is boiled with $10 \mathrm{ml}$ of chloroform and it was cooled accordingly. Then, 1 to 2 drops of concentrated sulfuric acid were added slowly through the wall of the tube. The mixtures were then shook well and it was allowed to stand for some time. The red color appears at the lower layer indicates the presence of steroids (Keo et al., 2017).

\section{Tannins Determination}

Test solution of $5 \mathrm{ml}$ ethanolic extract with $1 \%$ sodium hydroxide solution $(1 \%)$ provides yellow to red precipitation within short time indicates the presence of tannins (Keo et al., 2017).

\section{Triterpenoid Determination}

One $\mathrm{ml}$ of ethanolic extract of each sample is boiled in the mixture of $10 \mathrm{ml}$ chloroform and cooled down. One to two drops of concentrated sulfuric acid were added slowly through the wall of the tube. Shake tube well and allow standing for some time, reddish-purple colour appears at the lower layer indicates the presence of Triterpenoids (Keo et al., 2017).

\section{Alkaloids Determination}

Five ml of ethanolic extract was reacted with two drops of potassium bismuth iodide solution reagents in test-tubes. The development of creamy and orange colour respectively indicated positive result (Keo et al., 2017).

\section{Carbohydrate Determination}

The extract was hydrolyzed with $\mathrm{HCl}$ in the water heater. Then, it was added with 1 $\mathrm{ml}$ of pyridine and a few drops of sodium nitroprusside solution into the hydrolyzate, after it was etched with an alkaline solution of sodium hydroxide. The formation of pink to red colour indicates the presence of glycosides (Keo et al., 2017).

\section{Gas Chromatography-Mass Spectrometry Analysis (GC-MS Analysis)}

Gas Chromatography-Mass Spectrometry (G.C.-M.S.) analysis was carried out for the ethanolic extracts. The analysis was performed according to the GC-MS equipments by Shimadzu Q.P. 2010: R.T.X. - column type is 5 $\mathrm{ms}$, Restek Corp (30 $\mathrm{m}$ length). The injector and detector temperatures were both maintained at $250^{\circ} \mathrm{C}$, while operation temperature was set at $50-300^{\circ} \mathrm{C}$. The column temperature was programmed at $50-120^{\circ} \mathrm{C}$, with $40^{\circ} \mathrm{C}$ increment per minute which was maintained 
for one minute. Then, it was programmed at $120-300^{\circ} \mathrm{C}$, with $60^{\circ} \mathrm{C}$ increment per min and held for five minutes, with retention time (Rt) of 60 minutes. Helium was used as a carrier gas is $50-500$ atomic mass unit (A.M.U.). The compounds of each extract were identified by using computer searchers in commercial libraries of NIST (Maharani, Fernandes, Turjaman, Lukmandaru \& Kuspradini, 2016). Furthermore, the structure of chemical compounds associated with phytochemical and antioxidant tests determined will be drawn by using chemical office software.

\section{Organoleptic or Macroscopic Evaluation Analysis}

Based on observing, touching and sniffing senses, organoleptic analysis was carried out by a human panel (Xu et al., 2018). In this study, organoleptic analysis were conducted by comparing soup with bekai leaves addition (9 airdried leaves for $2 \mathrm{~L}$ ), soup with MSG addition (half-one teaspoon for $2 \mathrm{~L}$ ), and soup without any additional flavour (as a control). Organoleptic analysis of soup were carried out on 20 children in average 10-12 years old as panelist one by one by using Hedonic scale with 5 classifications (very dislike $=1$, dislike $=2$, neutral $=3$, like $=4$, and very like $=5$ ). They were decided on their favorite soup for sensory attributes of odor, flavour/taste and color.

\section{RESULT AND DISCUSSION}

\section{A. Phytochemical Test of Bekai Leaf}

Qualitative screening of bekai (Pycnarrbena tumefacta Miers) leaves ethanolic phytochemical compounds showed the presence of alkaloids, flavonoids, tannins and steroids. Previous study of other Pycnarrhena genus stated that Pycnarrhena longifolia leaves contained alkaloid (Masriani et al., 2013) and flavonoids (Mohammed et al., 2020). Meanwhile, others
Pycnarrhena manillensis included Philippine endemic medicinal plant, it leaves contained alkaloids and steroids (Ragasa, Tepora, \& Rideout, 2009). Another genus from West Kalimantan, Indonesia known locally as sengkubak root (Pycnarrbena cauliflora) has been determined for its alkaloid content which is identified as an anticancer compound (Masriani et al., 2014).

\section{B. Antioxidant Test of Bekai Leaf}

The result of the antioxidant test of bekai leaf using 2,2-diphenyl-1-picrylhydrazy (DPPH) method showed that concentrated extract had DPPH absorption reduction of $44.5 \%$ in $200 \mathrm{ppm}$ dilution, $68.1 \%$ in 100 ppm dilution, $80.1 \%$ in $50 \mathrm{ppm}$ dilution, and $83.2 \%$ in $25 \mathrm{ppm}$ dilution (Table 1). DPPH is used to test the ability of the compound to act as a free radical trap or hydrogen donor and evaluate the antioxidant activity (Devi \& Ganjewala, 2011). Antioxidant properties are very important in counteracting the deleterious role of free radicals in foods and biological systems (Pirbalouti, Firoznezhad, Craker, \& Akbarzadeh, 2013).

Antioxidant tested of bekai leaves using DPPH method showed that concentrated extract was $80.1 \%$, almost equivalent to high dose of Vitamin $\mathrm{C}$ of same genus, Tubu (Pycnarrbena longifolia) leaves that it had $87 \%$ antioxidant activity (Mohammed et al., 2020). The interpolation was calculated from 0 (zero) to the optimum concentration, which is between $0-83.2 \%$. The optimum reading of antioxidants is at a concentration of $25 \mathrm{ppm}$. As comparison, vitamin C $100 \mathrm{ppm}$ has an antioxidant of $97.1 \%$ and $96.1 \%$ in $50 \mathrm{ppm}$. The colour of sample can affected reading, a high concentration of sample colour is getting stronger or darker. In this study, bekai samples had a dark green blackest extracted colour. Sometimes the sample that containing phenolic

Table 1. Antioxidant test of bekai leaf with DPPH method

\begin{tabular}{ccccc}
\hline & $200 \mathrm{ppm}$ & $100 \mathrm{ppm}$ & $50 \mathrm{ppm}$ & $25 \mathrm{ppm}$ \\
\hline Bekai $(\%)$ & 44.5 & 68.1 & 80.1 & 83.2 \\
Vit C $(\%)$ & - & 97.1 & 96.1 & - \\
\hline
\end{tabular}


group such as anthocyanin, could have colour interference of the DPPH assay. The samples leads to under-estimation of antioxidant activity (Choong et al., 2007). Other study stated that a limitation of 2,2-diphenyl-1-picrylhydrazyl $(\mathrm{DPPH})$ radical scavenging ability (DRSA) due to the presence of pigments and colours in the extracts of plant-based foods was addressed. This fact could interferes the elaborate absorbance readings of DPPH radicals (Yeo \& Shahidi, 2019).

The high value of antioxidant of bekai leaves could improve human immune for inhibitory action of cancer cells, as well as almost $47 \%$ of anticancer drugs, come from the natural product (Jabeen, Hanif, Khan, \& Qadri, 2014). Consuming of foods rich in natural antioxidants, as well as processed foods enriched with them, provides the desired supply antioxidant and prevent potential diseases (Hardy, 2000; Jukic, Hmjica, \& Aldžic, 2015). Meanwhile, the evaluation of antioxidants with complex compounds are cannot be done singly. The DPPH method is based solely on removal of electrons which are replaced by hydrogen atoms from DPPH and is influenced by the polarity of compound (Gangwar et al., 2014).

\section{A Chemical Compound in Bekai Leaves Based on GC-MS Test}

The GC-MS test results (Figure 2, Table 2) indicated that the ethanol leaf extract of bekai contains five major compounds, ie 17.1\% Oxirane dodecyl, 14.1\% gamma sitosterol, $11.3 \%$ vitamin $\mathrm{E}$ ( $\alpha$ tokoferol), $10.7 \%$
9.12-Octadecadienoic acid (Z,Z)- (natural linoleic acid), 7.5\% 3-Tetradecanynoic acid (myristic acid). As well as major compound in bekai leaf, Gazzola (2016) stated that sodium dodecyl sulphate contained in fresh leaves of some natural products have been significant source of anticancer agents because of its antioxidant activity.

According to phytochemical tests, bekai leaves contained flavonoids, which are predicted to be able to provide various flavours in many food (Tanwar \& Modgil, 2012). Flavonoids belong to low molecular weight with phenolic compounds (Panche, Diwan, \& Chandra, 2016). Strong antioxidant activities in medicinal plants are due to the presence of phenolic compounds (Karau, Njagi, Machocho, Wangai, \& Nthinga, 2015). Flavonoids in bekai leaves was Phenol, 2,4-bis(1,1-dimethyl ethyl)-. Phenol, 2,4-bis(1,1dimethyl ethyl)- $\left(\mathrm{C}_{14} \mathrm{H}_{22} \mathrm{O}\right)$ detected in the third peak, $2.0 \%$ (Figure 3.). These components have same antioxidant properties as the major compound, oxiran dodexyl, which has flavouring agent properties due to include in same dodecyl group. This group is included in the list of chemical flavouring substances allowed for manufacturing of edible flavours (Customs Union Commission, 2011).

Bekai leaves were also contained alkaloids based on the phytochemical test. The alkaloid in food represented the bitter gustatory sensation (Astray, Rio, Mejuto, \& Pastrana , 2007). Alkaloids are low molecular weight, and nitrogen-containing compound (Matsuura \& Neto, 2015). Alkaloids in bekai leaves were

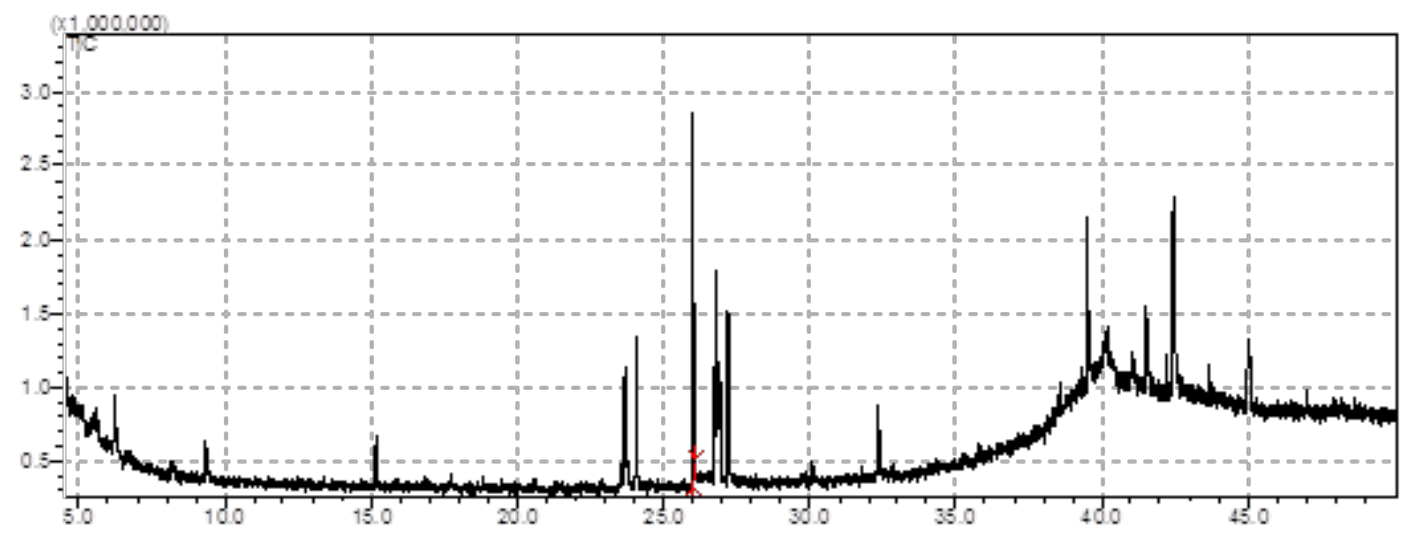

Figure 2. GC-MS analysis of bekai leaves 
Table 2. A chemical compound of bekai leaves extract based on GC-MS test result

\begin{tabular}{|c|c|c|c|c|c|}
\hline Peak\# & Ret.Time & Name & Mol.Form & $\begin{array}{c}\text { Area } \\
(\%)\end{array}$ & $\begin{array}{l}\text { Similarity } \\
\text { index }(\%)\end{array}$ \\
\hline 1 & 6.231 & Nonane, 2-methyl- & $\mathrm{C}_{10} \mathrm{H}_{22}$ & 2.8 & 90 \\
\hline 2 & 9.349 & Glutamine & $\mathrm{C}_{5} \mathrm{H}_{10} \mathrm{~N}_{2} \mathrm{O}_{3}$ & 1.1 & 93 \\
\hline 3 & 15.166 & Phenol, 2,4-bis(1,1-dimethylethyl)- & $\mathrm{C}_{14} \mathrm{H}_{22} \mathrm{O}$ & 2.0 & 91 \\
\hline 4 & 23.681 & Phthalic acid, dibutyl ester & $\mathrm{C}_{16} \mathrm{H}_{22} \mathrm{O}_{4}$ & 5.3 & 91 \\
\hline 5 & 24.062 & Palmitic acid, ethyl ester & $\mathrm{C}_{18} \mathrm{H}_{36} \mathrm{O}_{2}$ & 6.2 & 96 \\
\hline 6 & 26.023 & Oxirane, dodecyl- & $\mathrm{C}_{14} \mathrm{H}_{28} \mathrm{O}$ & 17.1 & 92 \\
\hline 7 & 26.784 & 9,12-Octadecadienoic acid (Z,Z)- & $\mathrm{C}_{21} \mathrm{H}_{38} \mathrm{O}_{4}$ & 10.7 & 95 \\
\hline 8 & 26.86 & 9-Octadecenoic acid, ethyl ester & $\mathrm{C}_{20} \mathrm{H}_{38} \mathrm{O}_{2}$ & 4.2 & 94 \\
\hline 9 & 26.899 & $\begin{array}{l}\text { 9,12,15-Octadecatrienoic acid, ethyl ester, } \\
\text { (Z,Z,Z)- }\end{array}$ & $\mathrm{C}_{20} \mathrm{H}_{34} \mathrm{O}_{2}$ & 4.2 & 91 \\
\hline 10 & 27.228 & 3-Tetradecanynoic acid & $\mathrm{C}_{14} \mathrm{H}_{24} \mathrm{O}_{2}$ & 7.5 & 90 \\
\hline 11 & 32.357 & Phthalic acid, mono-(2-ethylhexyl) ester & $\mathrm{C}_{16} \mathrm{H}_{22} \mathrm{O}_{4}$ & 3.5 & 90 \\
\hline 12 & 39.521 & Vitamin E (alpha tocopherol) & $\mathrm{C}_{29} \mathrm{H}_{50} \mathrm{O}_{2}$ & 11.3 & 96 \\
\hline 13 & 41.526 & $\begin{array}{l}\text { Pregn-5-en-3.beta.-ol, 20.alpha.- } \\
\text { [(1R,2R)-2-(1R)-1,2-dimethylpropyl-2- } \\
\text { methylcyclopropyl]- }\end{array}$ & $\mathrm{C}_{30} \mathrm{H}_{50} \mathrm{O}$ & 4.7 & 90 \\
\hline 14 & 42.465 & gamma.-Sitosterol & $\mathrm{C}_{29} \mathrm{H}_{50} \mathrm{O}$ & 14.1 & 97 \\
\hline 15 & 45.018 & $\begin{array}{l}\text { 9,19-Cyclolanost-25-en-3-ol, 24-methyl-, } \\
\text { (3.beta.,24S)- }\end{array}$ & $\mathrm{C}_{31} \mathrm{H}_{52} \mathrm{O}$ & 5.4 & 90 \\
\hline
\end{tabular}

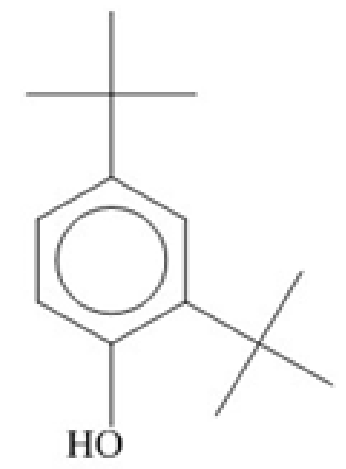

Phenol, 2,4-bis(1,1-dimethylethyl)-

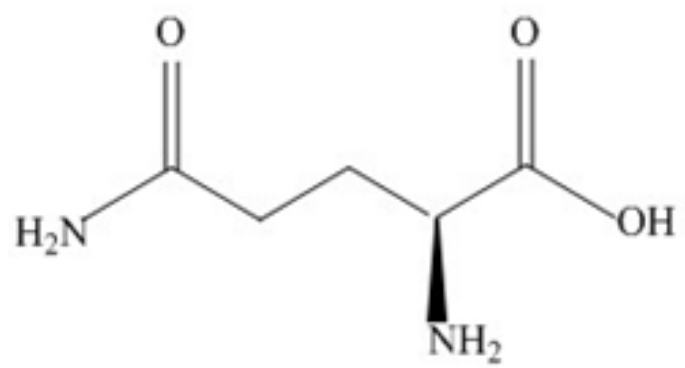

Glutamine

Figure 3. Phenol, 2,4-bis(1,1-dimethyl ethyl)- and glutamine suspected in fresh leaves of some natural products, as well as bekai leaves

identified as glutamine $\left(\mathrm{C}_{5} \mathrm{H}_{10} \mathrm{~N}_{2} \mathrm{O}_{3}\right)$. Glutamine detected in the second peak, $1.1 \%$. Glutamine is a conditionally essential amino acid widely used in sports nutrition due to $\mathrm{NH}_{2}\left(\mathrm{NH}_{2}\right.$ functional group) presences (Coqueiro et al., 2019). Furthermore, glutamine from snakehead fish could be increased glutathione, which has antioxidant activity in the human body and brain (Sunarno, 2015).
Steroids contained in bekai leaves were gamma sitosterol and $\alpha$-tocopherol (Figure 4.). $\alpha$-tocopherol detected in the $12^{\text {th }}$ peak, $11.3 \%$ considered to be one of the most powerful antioxidants (Fritsche, Wang, \& Jung, 2017). Kuchan et al. (2018) determined that $\alpha$-tocopherol plays an important role in protecting cell membrane. Meanwhile, gamma sitosterol detected in the 14th peak, $14.1 \%$, and 


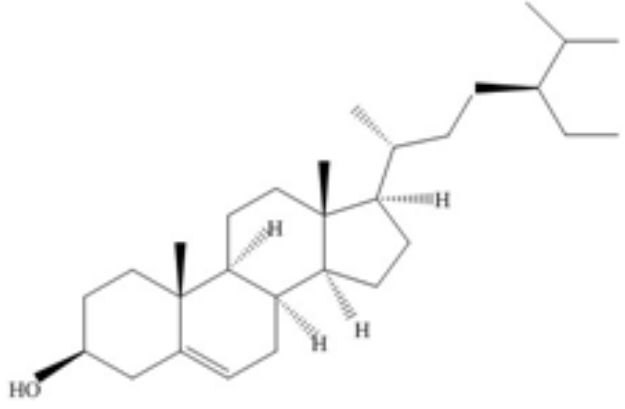

gamma sitosterol

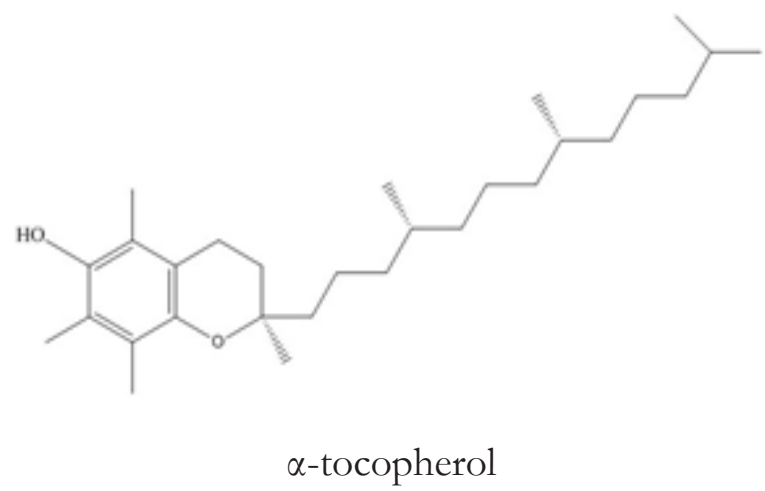

Figure 4. Gamma sitosterol and vitamin E ( $\alpha$ tocoferol) suspected in fresh leaves of some natural products, as well as bekai leaves

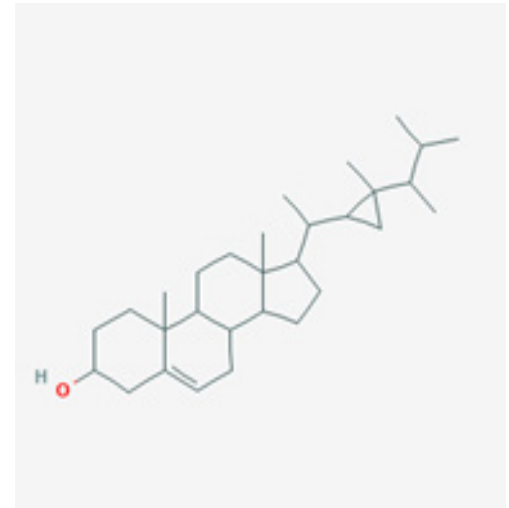

Pregn-5-en-3.beta.-ol, 20.alpha.-[(1R,2R)-2-(1R)-1,2 dimethylpropyl-2-methylcyclopropyl]-

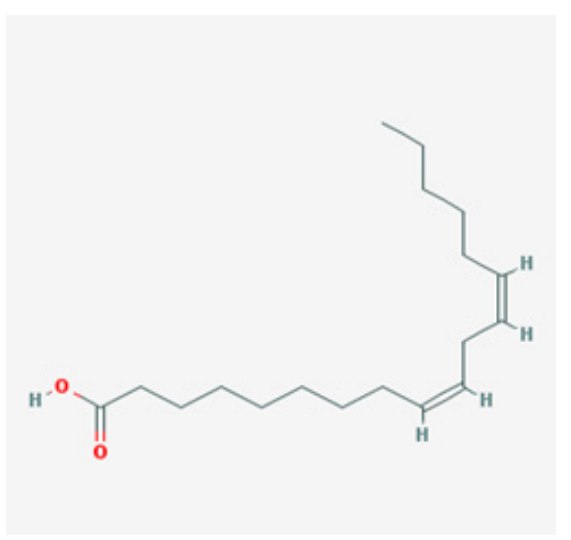

Linoleic acid

Figure 5. Pregn-5-en-3.beta.-ol, 20.alpha.-[(1R,2R)-2-(1R)-1,2 dimethylpropyl-2-methylcyclopropyl]and linoleic acid suspected in fresh leaves of some natural products, as well as bekai leaves

it can be considered as hypolipidemic agent (Balamurugan, Stalin, Aravinthan, \& Kim, 2014) and antihyperglicemyc activity (Sirikhansaeng, Tanee, Sudmoon, \& Chaveerach, 2017).

In addition, other chemical compounds that are included in the steroid group and contained in bekai leaves were Pregn-5en-3.beta.-ol, 20.alpha.-[(1R,2R)-2-(1R)-1,2 dimethylpropyl-2-methylcyclopropyl]known as gorgosterol detected in the $13^{\text {th }}$ peak, 4.69\% (Figure 5.). Pregn-5-en-3.beta.-ol, 20.alpha.-[(1R,2R)-2-(1R)-1,2 dimethylpropyl2-methylcyclopropyl]- that belong to pregnen compound. Cheenpracha et al. (2017) stated that Pregnen compound belong to the steroid group due to has a C-cyclic bond that showed its strong antioxidant activities.
It can be shown in Table 2, some fatty acids presented linoleic and myristic acid (9.12-Octadecadienoic acid (Z,Z)- (natural linoleic acid) detected in the $7^{\text {th }}$ peak, $10.7 \%$ ). Linoleic acid consumption can be used as optimal dietary human health (Jandacek, 2017). Linoleic acid has antioxidant activities, including free radical scavenging capacity (Ali et al, 2012). 3-Tetradecanynoic acid (myristic acid) detected in $10^{\text {th }}$ peak, $7.49 \%$. Myristic acid can be used as flavour agent in cuisine and commonly used in some food industries (Burdock \& Carabin, 2007). Myristic acid has antioxidant activities in vitro and hepatoprotective effects against carbon tetrachloride-induced acute liver injury (Liu, Yuan, Ramaswamy, Ren, \& Ren, 2019). 
On the other hand, esters were major components of flavour widely distributed in nature (Bayout et al., 2019). Bekai leaves contained esters, i.e. palmitic acid ethyl ester and 9-Octadecenoic acid, ethyl ester. Palmitic acid ethyl ester detected in the $5^{\text {th }}$ peak, 6.2\% (Table 2). Palmitic acid ethyl ester known as hexadecanoic acid ethyl ester, was reported as flavour activity (Gideon, 2015). Other biological activities were antioxidant, hypercholesterolemic, nematicide, pesticide, antiandrogenic flavour, haemolytic and alphareductase inhibitor (Sudha, Chidambarampillai, \& Mohan, 2013). 9-Octadecenoic acid, ethyl ester detected in the $8^{\text {th }}, 4.17 \%$. 9-Octadecenoic acid, ethyl ester had biological activity as hepatoprotective, anti-histaminic, antieczemic and hypocholesterolemic (Arora, Kumar, \& Meena, 2017).

\section{Organoleptic Test of Cuisine (soup) with Additional of Bekai Leaves Compared with MSG}

In order to maintain quality, purity, potency, safety, and efficacy of herbal drugs or product of medicinal plant needs sensory/organoleptic analysis as consumer acceptance (Patil et al., 2013; Vanhonacker et al., 2013). A sensory experience is described as an individual's perception of goods or services or other essentials in a service process as an image that challenges the human mind and senses. Thus, this sensory marketing is defined as a way of measuring and explaining consumer emotions as well as spotting and capitalizing on new market opportunities, and finally ensuring longlasting product success (Randhir et al., 2016).

Results of organoleptic tests presence in three soup variants can be shown in Table 3, as flavour agent for children's a flavour/taste perception.

Generally, most children prefered best (very like) in taste, colour and odour of soup with an additional of bekai leaves compared to MSG added and control (Table 3). Soup with an additional of bekai leaves was offered a unique odour/scent, savory/tasty, and no colour changing compared to both MSG added and control. A unique odour/scent in soup with an additional of bekai leaves described fresh scent and very tempting to taste it. Our sense of smell guards us safe by serving us to choose fresh food and avoid rotten/bad food. Various readings have considered the appeal of scents arising from an object, or a service associated with it being perceived as pleasant or unpleasant,

Table 3. Comparison of organoleptic tests presence in soup with addition of bekai leaf, MSG, and without both additional (control)

\begin{tabular}{|c|c|c|c|c|c|}
\hline Soup Variant & Class & Odour & Flavour & Colour & Remarks \\
\hline \multirow{5}{*}{$\begin{array}{c}\text { Soup with bekai } \\
\text { leaves }\end{array}$} & 1 & 0 & 0 & 0 & \multirow{5}{*}{$\begin{array}{l}\text { A unique smell/scent, savoury/ } \\
\text { tasty, and no colour changing }\end{array}$} \\
\hline & 2 & 0 & 0 & 0 & \\
\hline & 3 & 2 & 0 & 3 & \\
\hline & 4 & 7 & 4 & 2 & \\
\hline & 5 & 11 & 16 & 15 & \\
\hline \multirow{5}{*}{ Soup with MSG } & 1 & 0 & 0 & 0 & \multirow{5}{*}{$\begin{array}{l}\text { As usual/tasty, and more } \\
\text { colouring }\end{array}$} \\
\hline & 2 & 0 & 0 & 0 & \\
\hline & 3 & 4 & 0 & 7 & \\
\hline & 4 & 6 & 7 & 2 & \\
\hline & 5 & 10 & 13 & 11 & \\
\hline \multirow{5}{*}{$\begin{array}{l}\text { Soup without } \\
\text { bekai and MSG } \\
\quad \text { (control) }\end{array}$} & 1 & 0 & 0 & 0 & \multirow{5}{*}{$\begin{array}{l}\text { As usual/commonly tasty, and no } \\
\text { colour changing }\end{array}$} \\
\hline & 2 & 0 & 0 & 0 & \\
\hline & 3 & 3 & 3 & 7 & \\
\hline & 4 & 15 & 14 & 11 & \\
\hline & 5 & 2 & 3 & 2 & \\
\hline
\end{tabular}

Remarks : 20 children in average 10-12 years old ; - Hedonic scale with 5 classifications (very dislike $=1$, dislike $=2$, neutral $=3$, like $=4$, and very like $=5$ ) 
and also establishes a positive perception of a particular commercial environment (Bone \& Ellen, 1999; Chebat \& Michon, 2003).

The flavour or taste sense is the most important and most developed of all senses (Randhir et al., 2016). Organoleptic tests showed that the soup with the an addition of bekai leaves had a fresher, savory, and slightly sweet taste, when viewed from the children's perceptions as panelists who really like and have experience tasting in various types of soup. Furthermore, Randhir et al. (2016) stated that very few of our taste preferences are biologically preset. Much rather they are linked with some sort of experience. Once a flavour or food is accepted, this can also influence the preference for and acceptance of new flavours or foods. Another example of natural substance that could improve organoleptic test results is Mentha arvensis. The use of Mentha arvensis extract on whet-based pineapple mint beverages could improve the colour, taste, appearance and acceptability of the respondents (Kumar et al., 2017).

\section{CONCLUSION}

A recent study showed that the qualitative screening of phytochemical compounds in bekai leaves ethanolic extracts revealed the presence of alkaloids, flavonoids, tannins and steroids. Antioxidants of bekai leaves using DPPH method showed high activity $68.1 \%$ in $100 \mathrm{ppm}$, $80.1 \%$ in 50 ppm dilution, and $83.2 \%$ in 25 ppm dilution, respectively. Ethanol leaf extract of bekai contained five major compounds, i.e. Oxirane dodecyl, gamma sitosterol, vitamin E ( $\alpha$ tokoferol), 9.12-Octadecadienoic acid (Z, Z)(natural linoleic acid), and 3-Tetradecanynoic acid (myristic acid). Bekaileaves were considered to be one of the powerful antioxidants which can be used as a flavouring agent in cuisine and commonly used in some food industries.

Results of organoleptic (hedonic) tests presence in soup with bekai leaves added has been provided a unique smell, tasty without changing in original colour of soup compared with additional MSG and or control. It can be proved that soup with bekai leaves has been a preference for children's taste perceptions, even though the current generation is very comfortable and accustomed to adding MSG to their consumed food. Thus, this study provided an innovative product of herbal medicine served in cuisine (soup) that it would be predicted to attract consumers to the new market opportunities, and to promote general positive image for early generation consumers to prefer more healthy food.

\section{ACKNOWLEDGEMENT}

The authors want to express our sincere gratitude to $\mathrm{Mr}$ Amiril Saridan (taxonomist) for his contributions to this paper explicitly and intellectually. Sincere gratitude also goes to forest communities in Nyapa Indah Village, Berau, East Kalimantan for their beneficial assistances and valuable information related to this research undertaking until its completion.

\section{REFERENCES}

Ali, Y. M., Kadir, A. A., Ahmad, Z., Yaakub, H., Zakaria, Z. A., \& Abdullah, M. N. H. (2012). Free radical scavenging activity of conjugated linoleic acid as single or mixed isomers. Pharmaceutical Biology, 50(6), 712-719.

Almli, V.L., Verbeke, W., Vanhonacker, F., Naes, T., \& Hersleth, M. (2011). General image and attribute perceptions of traditional food in six European countries. Food Quality and Preference, 22, 129-138.

Arora, S., Kumar, G., \& Meena, S. (2017). Screening and evaluation of bioactive components of Cenchrus ciliaris L. by GC-MS Analysis. International Research Journal of Pharmacy, 8(6), 69-76.

Astray, G., Rio, L.G., Mejuto, J.C., \& Pastrana, L. (2007). Chemistry in food: Flavours. Journal of Environmental, Agricultural and Food Chemistry, 1742-1763.

Balamurugan, R., Stalin, A., Aravinthan, A., \& Kim, J.H. (2014). Gamma-sitoterol a potent hypolipidemic agent: in silico docking analysis. Medicinal Chemistry Research Journal. doi: //10.1007/s00044-014-1075-0.

Bayout, I., Bouzemi, N., Guo, N., Mao, X., Serra, S., Riva, S., \& Secundo, F. (2019). Natural flavor 
ester synthesis catalyzed by lipases. Flavour Fragrance Journal. doi:// 10.1002/ffj.3554.

Bisla, G., Choudhary, S., \& Chaudhary, V. (2014). Evaluation and organoleptic values of food products developed by incorporataed Catharanthus roseus (Sadabahar) fresh leaves explore their hypoglycemic potential. The Scientific World Journal. 1-5.

Bone, P. F., \& Ellen, P. S. (1999). Scents in the marketplace: Explaining a fraction of olfaction. Journal of Retailing, 75(2), 243-262.

Burdock, G., \& Carabin, I.G. (2007). Safety assessment of myristic acid as a food ingredient. Food and Chemical Toxicology journal, 45(4),517-29.

Chebat, J.-C., \& Michon, R. (2003). Impact of ambient odors on mall shoppers' emotions, cognition and spending: A test of competitive causal theories. Journal of Business Research, 56(7), 529-539.

Cheenpracha, S., Boapun, P., Ritthiwigrom, T. L. N., Laphookhieo, S., \& Pyne, S. G. (2017). Antimalarial and cytotoxic activities of pregnene-type steroidal alkaloids from Holarrhena pubescens Roots. National Product Research Journal, 24, 1-7.

Choong, C. T, Truonga, V. D., Roger F. M., Roger L. T., Kenneth V. P., \& Yencho, G.C. (2007). Antioxidant activities, phenolic and $\beta$-carotene contents of sweet potato genotypes with varying flesh colours. Food Chemistry, 103(3), 829-838.

Customs Union Commission. (2011). Uniform sanitary and epidemiological and hygienic safety requirements for food additives and flavourings (as amended by Decision of the Customs Union Commission No 889 of 9 December 2011).

Gangwar, M., Gautam, M.K., Sharma, A.K., Tripathi, Y.B., Goel, R.K., \& Nath, G. (2014). Antioxidant capacity and radical scavenging effect of polyphenol rich Mallotus philippenensis fruit extract on human erythrocytes: An in vitro study. The Scientific World Journal. doi://10.1155/2014/27945.

Gazzola, S. (2016). Natural products as leads for the synthesis of new anticancer compounds. (PhD Dissertation). Universitas Studiorum Insubriae, Como, Italy.

Coqueiro, A. Y., Rogero, M. M.,\& Tirapegui, J. (2019). Glutamine as an anti-fatigue amino acid in sport nutrition. Nutrients. doi:// 10.3390/nu11040863

Devi, S.A., \& Ganjewala, D. (2011). Antioxidant activities of methanolic extracts of sweet-flag (Acorus calamus) leaves and rhizomes. Journal of Herbs Spiced Medicinal Plants, 17, 1-11.

Fitriana, W. D., Istiqomah, S. B. T., Ersam, T., \& Fatmawati. (2018). The relationship of secondary metabolites: A study of Indonesian traditional herbal medicine (Jamu) for Post partum maternal care use. AIP Conference Proceedings 2049, doi://10.1063/1.5082501.

Fritsche, S., Wang, X., \& Jung, C. (2017). Biosynthesis in plants: An overview of key genes, functions, and breeding of vitamin E improved crops. Antioxidants, 6(99), doi: //10.3390/antiox6040099.

Ghosh, A.K., Banerjee, S., Mullick, H.I., \& Banerjee, J. (2011). Zingiber officinale: A natural gold. International Journal of Pharma and Bio Sciences, 2(1), 283-294.

Gideon, V.A. (2015). GC-MS Analysis of phytochemical components of Pseudoglochidion anamalayanum gamble: An endangered medicinal tree. Asian Journal of Plant Sciences and Research, 5(12), 36-41.

Hardy, G. (2000). Nutraceutical and functional foods: Introducing and meaning. Nutrition Journal, 16(7-8), 688-689.

Jabeen, S., Hanif, M.A., Khan, M.M., \& Qadri, R.W.K. (2014). Natural products sources and their active compound on disease prevention: A review. International Journal of Chemical and Biochemical Sciences, 6, 76-83.

Jandacek, R.J. (2017). Linoleic acid: A nutritional quandary. Healthcare journal, 5(25), doi: //10.3390/healthcare5020025.

Jaradat, N., Hussen, F., \& Ali, A. (2015). A preliminary phytochemical screening, qualitative estimation of total flavonoids, total phenols and antioxidant activity of Ephedra alata Decne. Journal of Material and Environmental Science, 6(6), 1771-1778.

Jukic, H., Hrnjica, D., \& Aldžic, A. (2015). The influence and the role of polyphenols on the sensory and organoleptic aspect of food. Hrana u zdravlju i bolesti, znanstveno-strućni časopis za nutricionizam $i$ dijetetiku, 4(2), 113-119.

Karau, G. M., Njagi, E. N. M., Machocho, A. K., Wangai, L. N., \& Nthinga, M. J. (2015). Chemical composition and in vitro antioxidant activities of Ocimum americanum. Advances in Analitical Chemistry, 5(2), 42-49. 
Kemp, S.E., Hollowood, T., and Hort, J. (2009). Sensory evalution. A practical handbook. Oxford: John Wiley \& Sons Ltd.

Keo, S., Meng, C., Oeung, S., Nov, V., Lon, S. A., Vichet, T., Va, T., Sourn, M., \& Chea, S. (2017). Preliminary phytochemical screening of selected medicinal plants of Cambodia. Asian Journal of Pharmacognosy, 1(4), 16-23

Kuchan, M., Mouthon, C.J., Dyer, R.A., Jensen, S.K., Schimpf, K.J., \& Innis, S.M. (2018). RRR- $\alpha-$ tocopherol is the predominant stereoisomer of $\alpha$-tocopherol in human milk. Current Developments in Nutrition Journal, 1-7.

Kumar, K., Singh, J., Chandra, S., \& Samsher. (2017). Formulation of whet based pinnapple herbal and its storage conditions. Chemical Science Review and Letters, 6(21), 198-203.

Liu, C., Yuan, C., Ramaswamy, H. S., Ren, Y., \& Ren, X. (2019). Antioxidant capacity and hepatoprotective activity of myristic acid acylated derivative of Phloridzin. Heliyon, 5. doi://10.1016/j.heliyon.2019.e01761.

Maharani, R., Fernandes, A., Turjaman, M., Lukmandaru, G., \& Kuspradini, H. (2016). The characterization of Phytochemical and GC-MS analysis on borneo agarwood (Aquilaria malaccensis Lamk) leaves and its utilization as an anti-browning in apple juice. IJPPR, 8(10), 1576-1582.

Maheswari, M.U., Reena, A., \& Sivaraj, C. (2017) GC-MS analysis, antioxidant and antibacterial of the brown algae, Padina tetratromatica. International Journal of Pharmaceutical Sciences and Research, 8(9), 4014-4020.

Masriani, Mustofa, Jumina, \& Sunarti. (2013). Pycnarrhena cauliflora ethanolic extract induces apoptosis and cell cycle arrest in hela human cervical cancer cells. International Journal of Research In Pharmaceutical And Biomedical Sciences, 4(4), 1060-1068.

Masriani, Mustofa, Jumina, Sunarti, \& Enawaty, E. (2014). Cytotoxic and pro-apotic activities of crude alkaloid from root of sengkubak (Pycnarrhena cauliflora (Miers) Diels) in human breast cancer T47D cell line. Scholar Academic Journal of Bioscience, 2(5), 336-340.

Matsuura, H. N., \& Neto, A. G. F. (2015). Plants alkaloids: Main features, toxicity, and mechanisms action. Plant Toxin. doi: //10.1007/978-94-007-6728-7_2-1.

Mohammed, N.K., Muhialdin, B.J., Masri, N.S., Sukor, R., Abd-El Aziem, F., \& Meor
Hussin, A.S. (2020). Chemical composition, antioxidant and antimicrobial activities of tubu (Pycnarrhena longifolia) leaves used as ingredient in traditional function foods. Food Research, 4(3), 823-830.

Niaz, K., Zaplatic, E., \& Spoor, J. (2018). Extensive use of monosodium glutamate : A threat to public health? EXCLI Journal, 17, 273-278.

Panche, A. N., Diwan, A. D., \& Chandra, S. R. (2016). Flavonoids: An overview. Journal of Nutritional Science, 5, 1-15.

Patil, S.G., Anita, S.W., Ramesh, C.P., \& Ambore, S. M. (2013). Standard tools for evaluation of herbal drugs: An overview. The Pharma Innovation Journal, 2(9), 60-65.

Pestoric, M., Simurina, O., Filipcev, B., Jambrec, D., Belovic, M., Misan, A., \& Nedeljkovic, N., (2015). Relationship of Physicochemical Characteristics with Sensory Profile of Cookies Enriched with Medicinal Herbs. International Journal of Food

Pirbalouti, A.G., Firoznezhad M., Craker L., \& Akbarzadeh, M. 2013. Essential oil compositions, antibacterial and antioxidant activities of various populations of Artemisia chamaemelifolia at two phenological stages. Rev. Bras. Farmacogn, 23, 861-869.

Ragasa, C.Y., Tepora, M.M., \& Rideout, J.A. (2009). Antimicrobial activities of sterol from Pycnarrhena manillensis. ACGC Chemmical Res. Comm, 23, 31-34.

Randhir, R., Latasha, K., Tooraiven, P., \& Monishan, B. (2016). Analyzing the impact of sensory marketing on consumers: A case study of K.F.C. Journal of US-China Public Administration, 13(4), 278-292.

Sauceda, A.E.Q., Martinez, M.O., Rodriguez, G.R.V., Aguilar, G.A.G., \& Zavala, J.F.A. (2016). Licorice (Glycyrrhiza glabra Linn.) oils. Essential Oils in Food Preservation, Flavor and Safety, 60, 523-530.

Shulammithi, R., Sharaya, M., Tejaswini, R.,\& Kiranmai, M. (2016). Standardization and quality evaluation of herbal drugs. IOSR Journal of Pharmacy and Biological Sciences, 11(51), 89-100.

Sirikhansaeng, P., Tanee, T, Sudmoon, R., \& Chaveerach, A. (2017). Major phytochemical as $\gamma$-sitosterol disclosing and toxicity testing in Langerstroemia species. Evidence-Based Complementary and Alternative Medicine, doi:// 10.1155/2017/7209851. 
Sudha, T., Chidambarampillai, S., \& Mohan, V.R. (2013). GC-MS analysis of bioactive components of aerial parts of Fluggea leucopyrus Willd. (Euphorbiaceae). Journal of Applied Pharmacentical Sciences, 3(5), 126-130.

Sunarno. (2015). Potential of glutathione antioxidant in the Hippocampus repair: Preliminary study on bioactive materials antiaging of snakehead fish (Channa striata) in animal models of aging. IJSE, 8(1), 22-25.

Supartono, W., Sukartiko, A. C., Yuliando, H., \& Kristanti, N. E. (2015). Possibility of some indigenous spices as flavor agent of green tea. Agriculture and Agricultural Sciece Procedia, 3, 6266.

Tanwar, B.,\& Modgil, R. (2012). Flavonoids: Dietary occurrence and health benefits. Spatula D.D., 2(1), 59-68.

Vanhonacker, F., Kühne, B., Gellynk, X., Guerrero, L., Hersleth, M., \& Verbeke, W. (2013). Innovations in traditional foods: impact on perceived traditional character and consumer acceptance. Food Research International, 54, 1828-1835.
Wong, L.F., Lim, Y.Y., \& Omar, M. (2008). Antioxidant and antimicrobial activities of some alpina species. Journal of Biochemistry, 33 , 835-851.

Xu, D., Lin, Y., Bauer, R., Chen, H.R., Yang, R.Q., Zou, H.Q., \& Yang, Y.H. (2018). Organoleptic evaluation of Amomi fructus and its further background verified via morphological measurement and GC coued with E-Nose. Evidence-Based Complementary and Alternative Medicine, 1-9.

Yeo, J. D., \& Shahidi, F. (2019). Critical re-evaluation of DPPH assay: Presence of pigments affects the results. J. Agric. Food Chem, 67(26), 75267529.

Zhang, Q.W., Lin, L.G., \& Ye, W.C. (2018). Techniques for extraction and isolation of natural products: A comprehensive review. Chin Med., 13: 20. 